Клименко О. М. [1; ORCID ID: 0000-0002-2047-8824],

д.С.-Г.н., професор Король Б. О. [1; ORCID ID: 0000-0002-2290-9376], к.е.н., доцент

${ }^{1}$ Національний університет водного господарства та природокористування, м. Рівне

\title{
ВИКОРИСТАННЯ МЕТОДУ SWОТ-АНАЛІЗУ ЯК ПЕРЕДУМОВА ЗАПРОВАДЖЕННЯ СТРАТЕГІЧНОГО І ОПЕРАЦІЙНОГО МЕНЕДЖМЕНТУ В КП «РІВНЕНСЬКА ОБЛАСНА ДИТЯЧА ЛІКАРНЯ»
}

У статті проаналізовано внутрішнє і зовнішнє середовища одного 3 провідних медичних закладів Рівненської області - комунального підприємства «Рівненська обласна дитяча лікарня». За результатами використаного методу SWOT-аналізу сформульовано візію, місію. Методом декомпозиції візія і місія деталізовані до рівня стратегічних цілей подальшого розвитку, що є головною передумовою запровадження стратегічного і операційного менеджменту на підприємстві.

Ключові слова: місія; візія; стратегія; SWOT-аналіз; стратегічний і операційний менеджмент; медична реформа; комунальне підприємство «Рівненська обласна дитяча лікарня» (КП «РОДЛ»).

Вступ. Українська система охорони здоров'я вже декілька років поспіль перебуває на етапі реформування: 31 квітня 2020 року розпочався 2 етап, відповідно до якого національні медичні заклади отримують фінансування від НСЗУ. В нових умовах заклади охорони здоров'я постали перед новими викликами: 1) навчитися самостійно шукати джерела фінансування; 2) аналізувати і обирати ефективні медичні технології; 3) моніторити та аналізувати ринки медичних послуг; 4) налагоджувати ефективні комунікації з пацієнтами та ін.

Вирішення нових завдань для кожного медичного закладу суттєво полегшується завдяки запровадженню процесів стратегування: уточненню своєї ролі у зовнішньому середовищі місії; конкретизації бачення свого майбутнього стану - візії; усвідомлення переваг для власних працівників - мети; підготовці головного документа - стратегії, який варто легітимізувати на загальних зборах працівників і ознайомити з ним ключових стейкголдерів.

Проте значна кількість медичних закладів досі не змогла 
ефективно адаптуватися до нових соціально-економічних умов свого функціонування 3 причин браку знань і досвіду застосування сучасних методів та інструментів стратегічного і операційного менеджменту. Серед таких методів найбільш популярним є метод SWOT-аналізу, який використовується передусім в стратегічній діагностиці середовища, в якому функціонує підприємство, і $€$ передумовою подальшого розроблення стратегічних документів.

Аналіз останніх досліджень. Питання практичного досвіду використання SWOT-аналізу як важливого інструменту процесів стратегування широко висвітлені у численних публікаціях вітчизняних теоретиків і практиків, серед яких варто відзначити праці: Нємцова В. Д., Л. Є. Довгань [1], 3. Є. Шершньової [2], Кіндрацької Г. І. [3], Тоцької О. Л. [4], а також зарубіжних І. Ансоффа [5], Ж.-Ж. Ламбена [6], М. Портера [7] та багатьох ін. Їх праці стосуються розгляду різних методів стратегічної діагностики, особливо на етапі стратегічного планування, в тому числі й методу SWOT-аналізу. Незважаючи на достатньо глибоку опрацьованість теоретико-методологічної бази, актуальними залишаються питання удосконалення методичних основ і практичного впровадження SWOT-аналізу в діяльність українських медичних закладів.

Постановка завдання. Необхідність проведення SWOT-аналізу як етапу процесу розроблення Стратегії розвитку КП «РОДЛ» була спричинена такими явищами й процесами: а) відсутністю затвердженої стратегії розвитку підприємства; б) глобальними викликами, які виникли перед українськими медичними закладами; в) ризиками, які постали перед економікою України в останні роки; г) тенденціями, що склалися в розвитку медицини в $Є C$; д) підписанням Угоди про асоціацію з ЄС; е) запитами керівництва підприємства на впровадження стратегічного і операційного менеджменту.

Виклад основного матеріалу. SWOT-аналіз комунального підприємства «Рівненська обласна дитяча лікарня (надалі - КП «РОДЛ») здійснювався робочою групою підприємства із залученням за згодою працівників кафедри менеджменту Національного університету водного господарства та природокористування, експертів громадської організації «Регіональний центр євроінтеграційних проектів» [8]. За основу було взято показники соціально-економічного становища та перспективи розвитку КП «РОДЛ», висновки з результатів позиціювання підприємства в різних масштабах, результати виявлення глобальних викликів i дослідження національних ризиків в галузі медицини, тенденцій розвитку медичної галузі в умовах реформи, а також виявлення 
проблем і точок розвитку підприємства, які зауважили його працівники і члени робочої групи [5].

Використання інструменту SWOT-аналізу для КП «РОДЛ» дозволило детально проаналізувати взаємозв'язок між складовими його зовнішнього і внутрішнього середовищ та забезпечити основу для ефективного прийняття стратегічних управлінських рішень. Метою застосування SWOT-аналізу є виявлення чинників і явищ, що визначають розвиток підприємства, з розподілом на чотири групи: сильні (Strengths) та слабкі (Weaknesses) сторони, можливості (Opportunities) та загрози (Threats).

Сильні сторони показують конкурентну перевагу КП «РОДЛ» стосовно інших медичних закладів, слабкі сторони - це множина внутрішніх факторів, що гальмують ефективний розвиток підприємства. Можливостями є тенденції чи події у зовнішньому середовищі, вчасно реагуючи на які керівництво медичного закладу може значно швидше реалізувати поставлені цілі. Загрозами $є$ сукупність факторів, що потенційно можуть негативно впливати на лікарню за умови невчасного реагування на них.

Перелік факторів матриці SWOT-аналізу діяльності КП «РОДЛ» відображено в табл. 1, 2.

Таблиця 1

Перелік сильних і слабких сторін внутрішнього

середовища КП «РОДЛ»

\begin{tabular}{|c|c|}
\hline \multicolumn{2}{|c|}{ ВНУТРІШНЄ СЕРЕДОВИЩЕ } \\
\hline СИЛЬНІ СТОРОНИ & СЛАБКІ СТОРОНИ \\
\hline 1 & 2 \\
\hline \multicolumn{2}{|c|}{ 1. Економічний потенціал } \\
\hline $\begin{array}{l}\text { - Стабільне централізоване постачання } \\
\text { медикаментів і виробів медичного } \\
\text { призначення } \\
\text { - Наявність регіональної програми } \\
\text { фінансування «Діти Рівненщини» } \\
\text { - Монопольне становище лікарні на ринку } \\
\text { надання медичних послуг дитячому } \\
\text { населенню області (до 70\%) }\end{array}$ & 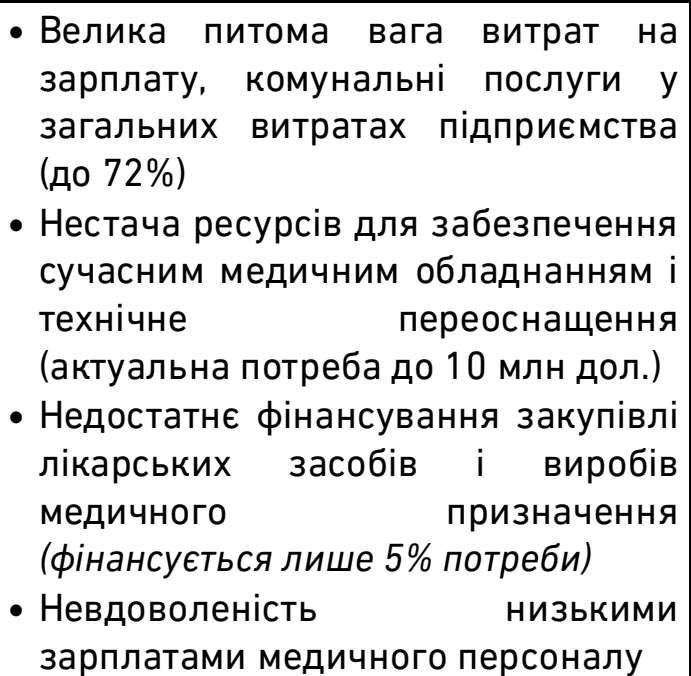 \\
\hline 2. Лाкувальн & ичний потенціал \\
\hline $\begin{array}{l}\text { - Повний замкнутий цикл лікувального } \\
\text { процесу }\end{array}$ & $\begin{array}{l}\text { - Низький рівень впровадження в } \\
\text { діяльність лікарні стандартів та } \\
\text { протоколів медичної допомоги }\end{array}$ \\
\hline
\end{tabular}


продовження табл. 1

\begin{tabular}{|c|c|}
\hline \begin{tabular}{|l} 
- Оснащені фаховим персоналом та \\
$\begin{array}{l}\text { обладнанням хірургічне } \\
\text { неонатологічне відділення }\end{array}$ \\
\end{tabular} & з причин їх відсутності на рівні М03 \\
\hline $\begin{array}{l}\text { - Сформований позитивний імідж лікарні } \\
\text { в населення Рівненської області }\end{array}$ & $\begin{array}{l}\text { - Низька конкурентоспроможність } \\
\text { офтальмологічного } \\
\text { отоларингологічного відділень }\end{array}$ \\
\hline \multicolumn{2}{|c|}{ 3. Технічний та інноваційний потенціал } \\
\hline $\begin{array}{l}\text { - Впроваджена система управління } \\
\text { якістю ISO 9001:2015 } \\
\text { - Створена локальна комп'ютеризована } \\
\text { мережа в усіх підрозділах підприємства } \\
\text { - } 32018 \text { року запроваджено медичну } \\
\text { інформаційну систему «Каштан» }\end{array}$ & $\begin{array}{l}\text { - Наявні збої в роботі медичної } \\
\text { інформаційної системи } \\
\text { - Нестача сучасного медичного } \\
\text { обладнання для проведення } \\
\text { складних операцій і діагностики }\end{array}$ \\
\hline \multicolumn{2}{|c|}{ 4. Інвестиційний потенціал } \\
\hline $\begin{array}{l}\text { - Досвід у написанні проєктів та їх } \\
\text { впровадженні } \\
\text { - Налагоджена міжнародна співпраця з } \\
\text { дитячою лікарнею м. Ольштин (Польща), } \\
\text { НДІ ПАГ АМНУ України }\end{array}$ & $\begin{array}{l}\text { - Недостать } \\
\text { коштів }\end{array}$ \\
\hline
\end{tabular}

- Висококваліфікований штат лікарів - Брак

- Розроблено та впроваджується система правил корпоративної етики і правил професійного спілкування з пацієнтами медичних сестер 3 причин ї трудової міграції в країни ЄС

- Недостатній контроль за дотриманням «Правил професійної етики і корпоративного спілкування» персоналом лікарні

\section{6. Інфраструктура}

- Зручне розташування закладу поблизу - Занадто складні маршрути транспортної мережі області переміщення пацієнтів лікарнею 3 причин великої кількості будівель

- Близьке розташування обласного центру Волинської області м. Луцька, куди звертається за медичною допомогою значна частина дитячого населення Дубенського району Рівненської області

\section{7. Матеріально-технічна база}

- Наявність власної матеріально-технічної - Надто низька енергоефективність бази

- Високий рівень забезпечення комп'ютерною технікою (80\%) будівель медичних корпусів № 1, 2, 3 Відсутність однолінійної схеми енергоживлення в медичних корпусах № 1-3, поліклініці й інфекційно-боксованому корпусі 
продовження табл. 1

\begin{tabular}{|c|c|}
\hline & $\begin{array}{l}\text { - Відсутність дизель-генератора для } \\
\text { постачання електроенергії у випадку } \\
\text { настання аварійних ситуацій } \\
\text { - Невідповідність системи вентиляції } \\
\text { санітарно-гігієнічним нормам в } \\
\text { медичних корпусах } \\
\text { - Невідповідність Правилам пожежної } \\
\text { безпеки в закладах охорони } \\
\text { здоров'я с } \\
\text { Застарілість } \\
\text { водопостачання і водовідведення }\end{array}$ \\
\hline \multicolumn{2}{|c|}{ 8. Управління } \\
\hline $\begin{array}{l}\text { - Сформовані місія, цінності та місце } \\
\text { лікарні, зокрема при наданні } \\
\text { високоспеціалізованої } \\
\text { допомоги дітям Рівненської області } \\
\text { - Впроваджено лінійно-функціональну } \\
\text { структуру управління лікарнею } \\
\text { - Наявність власного сайту підприємства і } \\
\text { сторінки у Facebook }\end{array}$ & $\begin{array}{l}\text { - Громіздка організаційна структура } \\
\text { управління підприємства } \\
\text { - Невдалі дизайн і наповнення } \\
\text { власного сайту підприємства }\end{array}$ \\
\hline
\end{tabular}

SWOT-матриця сприяє виявленню взаємозв'язків між «внутрішніми» (сильними і слабкими сторони) і «зовнішніми» (можливостями і загрозами) чинниками, що мають стратегічне значення для КП «РОДЛ». Суцільна лінія схематично відображає сильний взаємозв'язок, пунктирна лінія - слабкий. Виявлені взаємозв'язки дозволили визначити порівняльні переваги, виклики, а також ризики, що лягли в основу стратегічного вибору формулювання стратегічних і операційних цілей розвитку лікарні в довгостроковій перспективі.

Таблиця 2

Перелік можливостей і загроз зовнішнього середовища КП «РОДЛ»

\begin{tabular}{|c|c|}
\hline \multicolumn{2}{|c|}{ ЗОВНІШНЄ СЕРЕДОВИЩЕ } \\
\hline МОЖЛИВОСТІ & ЗАГРОЗИ \\
\hline 1 & 2 \\
\hline \multicolumn{2}{|c|}{ 1. Політичні фактори } \\
\hline $\begin{array}{lr}\text { - Участь } \quad \text { в } & \text { пілотному } \\
\text { впровадження } & \text { проєкті } \\
\text { споріднених груп } & \end{array}$ & $\begin{array}{l}\text { - Нестабільна і важкопрогнс } \\
\text { економічна ситуація в Україні } \\
\text { числі через війну в Донбасі }\end{array}$ \\
\hline $\begin{array}{l}\text { - Здобуття додаткових потоків пацієнтів з } \\
\text { причин вдалого географічного } \\
\text { розташування поблизу центральної }\end{array}$ & $\begin{array}{lr}\text { - Декларативність } & \text { і } \text { фінансова } \\
\text { незабезпеченість } & \text { безоплатності } \\
\text { медичної допомоги } & \end{array}$ \\
\hline $\begin{array}{l}\text { частини країни, достатньої кількості } \\
\text { кваліфікованого медичного персоналу } \\
\text { та сучасного обладнання }\end{array}$ & $\begin{array}{l}\text { - Відставання від запланованих } \\
\text { строків медичної реформи в Україні } \\
\text { - Створення госпітальних округів у } \\
\text { містах Дубно, Рівне, Сарни }\end{array}$ \\
\hline
\end{tabular}


продовження табл. 2

\begin{tabular}{|c|c|}
\hline \multicolumn{2}{|c|}{ 2. Економічні фактори } \\
\hline $\begin{array}{l}\text { - Визнання платності медицини } \\
\text { державою } \\
\text { - Залучення ключових стейкголдерів до } \\
\text { збільшення капітальних інвестицій } \\
\text { (відповідно до нової Стратегії лікарні) } \\
\text { - Прийняття й імплементація Закону «Про } \\
\text { обов'язкове загальнодержавне медичне } \\
\text { страхування» } \\
\text { - Підвищення платоспроможності } \\
\text { населення за рахунок його залучення } \\
\text { до схем страхування чи інших форм } \\
\text { оплати медичнихпослуг }\end{array}$ & $\begin{array}{l}\text { - Невизначеність } \\
\text { медичної послуги і гарантованого } \\
\text { обсягу медичної допомоги на } \\
\text { національному рівні } \\
\text { - Наявність неофіційних платежів } \\
\text { - Висока залежність від державних } \\
\text { субвенцій }\end{array}$ \\
\hline \multicolumn{2}{|c|}{ 3. Соціальні фактори } \\
\hline $\begin{array}{l}\text { - Підвищення ролі трудового колективу в } \\
\text { управлінні підприємством }\end{array}$ & $\begin{array}{l}\text { - Зниження рівня соціального захисту } \\
\text { значної частки населення }\end{array}$ \\
\hline $\begin{array}{l}\text { - Отримання іноземних, державних і } \\
\text { місцевих грантів на поліпшення умов } \\
\text { праці персоналу лікарні } \\
\text { - Підвищення лікувально-діагностичного, } \\
\text { економічного, технічного, інноваційно- } \\
\text { інвестиційного і трудового потенціалів } \\
\text { лікарні, матеріально-технічної бази й } \\
\text { інфраструктури }\end{array}$ & $\begin{array}{l}\text { - Негативна тенденція до зменшення } \\
\text { кількості дитячого населення } \\
\text { Рівненської області } \\
\text { - Трудова міграція медичного та } \\
\text { обслуговуючого персоналу за } \\
\text { кордон у зв'язку з низьким рівнем } \\
\text { зарплат в Україні }\end{array}$ \\
\hline \multicolumn{2}{|c|}{ 4. Технологічні фактори } \\
\hline $\begin{array}{l}\text { - Впровадження медичної інформаційної } \\
\text { системи в лікарні } \\
\text { - Створення локальних протоколів } \\
\text { лікування на основі доказової медицини }\end{array}$ & $\begin{array}{l}\text { - Нормативно-правові обмеження на } \\
\text { трансфер новітніх медичних } \\
\text { технологій в Україну (в цілому до } \\
\text { країн, що розвиваються) з боку } \\
\text { інноваційних країн-лідерів }\end{array}$ \\
\hline
\end{tabular}

Порівняльні переваги можна визначити на основі аналізу сильних сторін і можливостей організації. Сильні сторони можуть суттєво посилюватися за рахунок ефективної реалізації можливостей КП РОДЛ» (рис. 1).

Виклики визначаються в результаті аналізу слабких сторін і можливостей. У випадку успішної реалізації можливостей КП «РОДЛ» зможе послабити дію слабких сторін (рис. 2).

Ризики («негативні») формуються на основі аналізу слабких сторін та загроз. У випадку реалізації якоїсь із загроз вплив слабких сторін стає набагато відчутнішим (рис. 3). 


\begin{tabular}{|c|c|}
\hline Сильні сторони & Момлиивості \\
\hline $\begin{array}{l}\text { 1. Велика частка лікарні на ринку надання } \\
\text { медичних послуг (до 70\%) }\end{array}$ & $\begin{array}{l}\text { 1. Участо у пілотному проекті із впровадження } \\
\text { діагностично-споріднених груп }\end{array}$ \\
\hline 2. Замкнутий цикл лікувального процесу & 2. Отриямання додаткоеих потоків паціентів \\
\hline $\begin{array}{l}\text { 3. Фаховий персонал і ефектияне } \\
\text { обладнання }\end{array}$ & 3. Визнання платності медицини державою \\
\hline $\begin{array}{l}\text { 4. Впроваджена система управління } \\
\text { якістю ISO 9001:2015 }\end{array}$ & $\begin{array}{l}\text { 4. Залучення зацјкавлених сторін до процесів } \\
\text { інвестування }\end{array}$ \\
\hline $\begin{array}{l}\text { 5. Наявна локальна комп'ютеризована } \\
\text { мережа в усіх підрозділах }\end{array}$ & $\begin{array}{l}\text { 5. Набуття чинності законодавства про медичне } \\
\text { страхування }\end{array}$ \\
\hline $\begin{array}{l}\text { 6. Розпочато впровадження медичної } \\
\text { інформаційної системи «Каштан” }\end{array}$ & 6. Зростання платоспроможності населення \\
\hline $\begin{array}{l}\text { 7. Досвід у написанні і впровадженні } \\
\text { провктів }\end{array}$ & 7. Надання нових прибуткових послуг \\
\hline $\begin{array}{l}\text { 8. Налагоджена співпраця з } \\
\text { міжнародними партнерами і науковими } \\
\text { закладами }\end{array}$ & $\begin{array}{l}\text { 8. Підвищеннн ролі трудового колективу в } \\
\text { управлінні підприємством }\end{array}$ \\
\hline $\begin{array}{l}\text { 9. Розроблено і впроваджуються Правила } \\
\text { корпоративної етики }\end{array}$ & $\begin{array}{l}\text { 9. Отримання вітчизняних і закордонних } \\
\text { грантів }\end{array}$ \\
\hline $\begin{array}{l}\text { 10. Зручне локація закладу поблизу } \\
\text { транспортної мережі області }\end{array}$ & $\begin{array}{l}\text { 10. Впроеадження єдиної медичної } \\
\text { інформаційної системи }\end{array}$ \\
\hline $\begin{array}{l}\text { 11. Висококваліфікований штат лікарів } \\
\text { (96\% мають вищу категоріко) }\end{array}$ & 11. Створення локальних протоколів лікування \\
\hline $\begin{array}{l}\text { 12. Наявністо власного сайту } \\
\text { підприемства та сторінки у Facebook }\end{array}$ & \\
\hline
\end{tabular}

\section{Рис. 1. Порівняльні переваги КП «РОДЛ»}

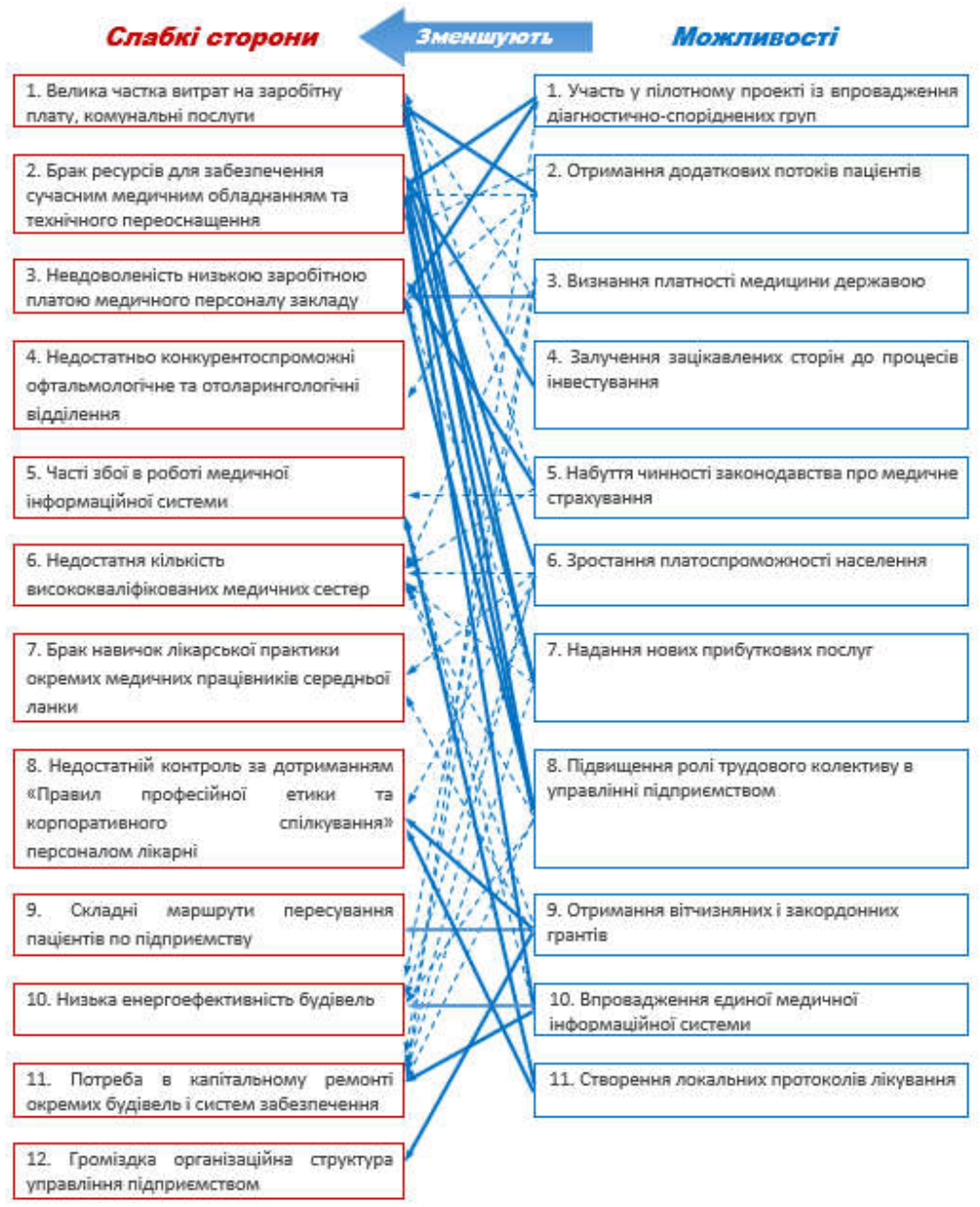

Рис. 2. Виклики КП «РОДЛ» 


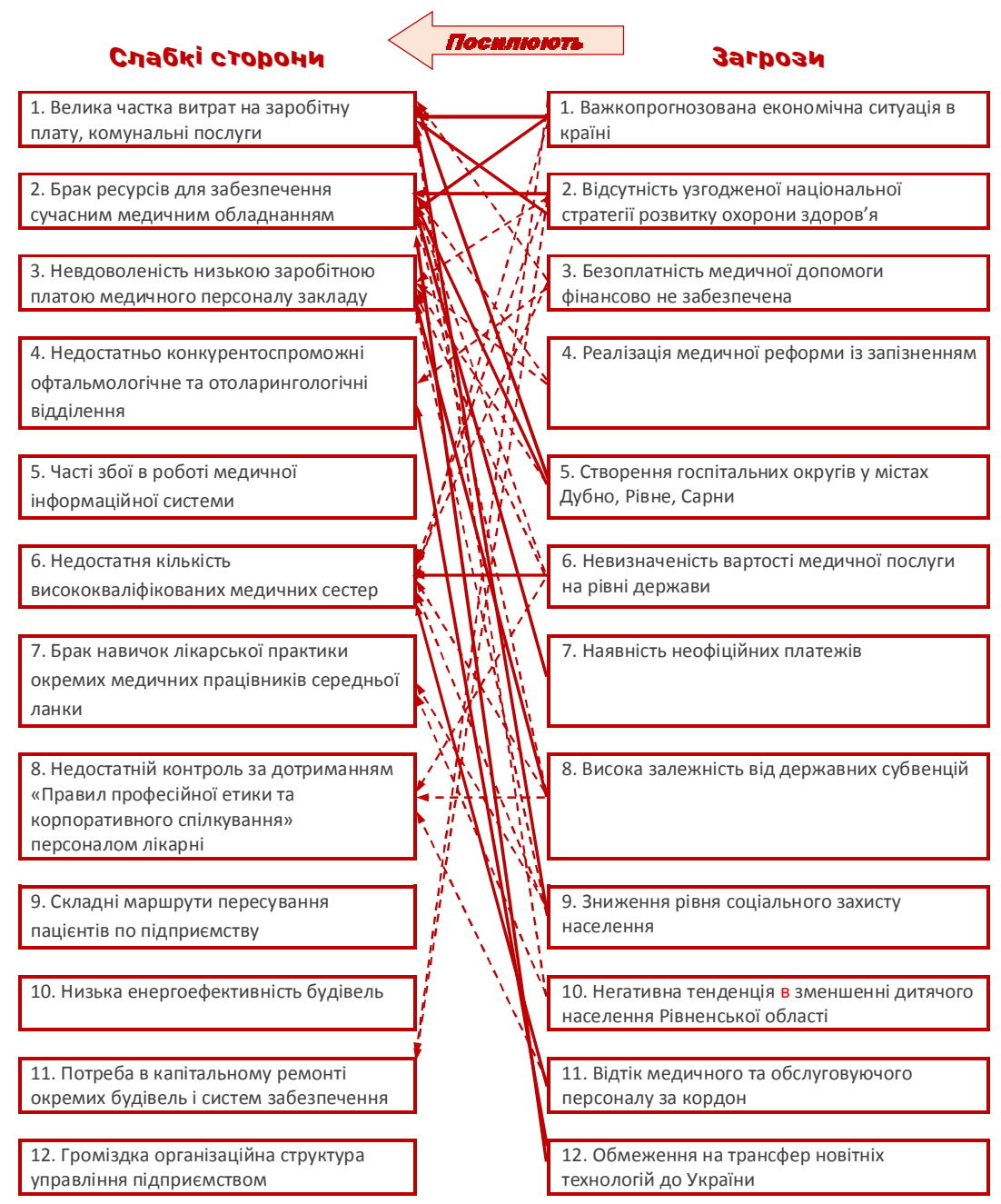

Рис. 3. Ризики КП «РОДЛ»

Ґрунтуючись на результатах воркшопів робочої групи 3 розробки Стратегії, колективних засідань персоналу КП «РОДЛ», лікарів-обласних медичних експертів, а також 3 урахуванням результатів SWOT-аналізу (дозволив визначити головні проблеми лікарні i їі конкурентні переваги), було прийнято консенсусне рішення, що місія КП «РОДЛ» має узгоджуватися із загальною місією Рівненської області. Також місія і візія КП «РОДЛ» здобули організаційну легітимність на Колективних зборах працівників лікарні, коли заслуховувалися пропозиції та затверджувався остаточний варіант формулювання цих важливих орієнтирів подальшого стратегічного розвитку.

Місія КП «РОДЛ» - надання дітям Рівненської області безпечних і високоспеціалізованих медичних послуг найвищої якості в затишних і комфортних умовах.

Візія КП «РОДЛ» - сучасна європейська багатопрофільна лікарня, що надає широкий високоспеціалізований та унікальний 
спектр високоякісних медичних послуг дітям Рівненської області.

Широкий і унікальний спектр передбачає використання наявного в КП «РОДЛ» повного спектру медичних послуг, враховуючи насамперед послуги висококваліфікованої інтенсивної терапії, неонатології, високоспеціалізованої хірургічної допомоги, а також інші унікальні напрямки, які $\epsilon$ і будуть в майбутньому притаманні лише цьому лікувальному закладу в Рівненській області.

На Колективних зборах працівників лікарні в грудні 2019 року було затверджено стратегічні цілі (орієнтири) розвитку КП «Рівненська обласна дитяча лікарня» на період до 2025 року: 1) підвищення ефективності лікувального процесу; 2) підвищення рівня задоволеності пацієнтів та формування позитивного іміджу в регіоні; 3) підвищення фінансово-економічної стабільності підприємства; 4) приведення матеріально-технічної бази у відповідність до вимог лікарні європейського рівня обслуговування.

Висновки. В результаті роботи над проєктом стратегії розвитку КП «РОДЛ», одним з важливих процесів чого був проведений SWOTаналіз, можна виділити шість основних етапів стратегування, які можуть бути використані як рекомендації для аналогічного розроблення стратегії розвитку інших медичних закладів: 1 етап підготовка проєкту про формування робочої групи, який затверджує головний лікар; 2 етап - проведення тематичних «круглих столів», «майстер-класів» з обговорення проблем розвитку підприємства і формування фокус-груп; 3 етап - проведення соціологічних опитувань персоналу, членів робочої групи; 4 етап - формування проєкту стратегії робочою групою із залученням науковців; 5 етап обговорення проєкту Стратегії на спільному «круглому столі» за участю керівників структурних підрозділів; 6 етап - затвердження стратегії на загальних зборах працівників медичного закладу із залученням ключових стейкголдерів.

Досягнення стратегічних цілей буде ефективним орієнтиром наближення до візії та виконання місії підприємства, а також стане основою для формулювання операційних цілей і подальшого впровадження операційного менеджменту в КП «РОДЛ».

1. Немцов В. Д., Довгань Л. Є. Стратегічний менеджмент : навч. посіб. К. : «ЕкспресПоліграф», 2002. 560 с. 2. Шершньова 3. Є. Стратегічне управління : підручник. 2-ге вид., перероб. і доп. К.: КНЕУ, 2004. 699 с. 3. КіндрацькаГ.І. Стратегічний менеджмент : навч. посіб. К.: Знання, 2006. 366 с. 4. Стратегічне дослідження регіонів України за допомогою SWOT-аналізу : кол. моногр. / за ред. О. Л. Тоцької. Луцьк: Східноєвроп. нац. ун-т ім. Лесі Українки, 2013. 180 с. 5. Ансофф И. Стратегический менеджмент. Классическое издание. 1-е изд. СПб. : Питер, 2009. 
344 с. 6. Ламбен Жан-Жак. Стратегический маркетинг. Европейская перспектива / пер. с французского. СПб. : Наука, 1996. 589 с. 7. Портер М. Конкурентная стратегия. Методика анализа отраслей и конкурентов. М. : Альпина Бизнес Букс, 2007. 464 с. 8. Стратегія розвитку комунального підприємства «Рівненська обласна дитяча лікарня» Рівненської обласної ради на період 2020-2025 pp. / Л. Ф. Кожушко, Б. О. Король, Р. М. Костюкевич, Н. А.Фроленкова, В. Я. Бойко, А.І.Кирилюк, Л.С. Філик ; за заг. ред. Б. О. Короля. URL: https://drive.google.com/file/d/1nJ_lxkqFkdIRU3z5eon6gpFYNeifW9Ed/view. (дата звернення: 15.05.2021).

\section{REFERENCES:}

1. Nemtsov V. D., Dovhan L. Ye. Stratehichnyi menedzhment : navch. posib. K. : «Ekspres-Polihraf», 2002. 560 s. 2. Shershnova Z. Ye. Stratehichne upravlinnia : pidruchnyk. 2-he vyd., pererob. i dop. K. : KNEU, 2004. 699 s. 3. Kindratska H. I. Stratehichnyi menedzhment : navch. posib. K. : Znannia, 2006. 366 s. 4. Stratehichne doslidzhennia rehioniv Ukrainy za dopomohoiu SWOT-analizu : kol. monohr. / za red. O. L. Totskoi. Lutsk : Skhidnoievrop. nats. un-t im. Lesi Ukrainky, 2013. 180 s. 5. Ansoff I. Strategicheskiy menedjment. Klassicheskoe izdanie. 1-e izd. SPb. : Piter, 2009. 344 s. 6. Lamben Jan-Jak. Strategicheskiy marketing. Evropeyskaya perspektiva / per. s frantsuzskogo. SPb. : Nauka, 1996. 589 s. 7. Porter M. Konkurentnaya strategiya. Metodika analiza otrasley i konkurentov. M. : Alpina Biznes Buks, 2007. 464 s. 8. «Stratehiia rozvytku komunalnoho pidpryiemstva «Rivnenska oblasna dytiacha likarnia» Rivnenskoi oblasnoi rady na period 2020-2025 rr.» / L. F. Kozhushko, B. O. Korol, R. M. Kostiukevych, N. A. Frolenkova, V. Ya. Boiko, A. I. Kyryliuk, L. S. Filyk ; za zah. $\quad$ red. $\quad$ B. $0 . \quad$ Korolia. URL: https://drive.google.com/file/d/1nJ_lxkqFkdIRU3z5eon6gpFYNeifW9Ed/view. (data zvernennia: 15.05.2021).

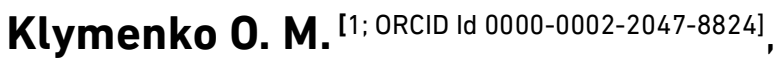
Doctor of Agricultural Science, Professor,

Korol B. O. [1; ORCID Id 0000-0002-2290-9376], Candidate of Economics (Ph.D.), Associate Professor

${ }^{1}$ National University of Water and Environmental Engineering, Rivne

\section{USING OF SWOT-ANALYSIS METHOD AS A PRECONDITION FOR INTRODUCTION OF STRATEGIC AND OPERATIONAL MANAGEMENT IN MUNICIPAL ENTERPRISE «RIVNE REGIONAL CHILDREN'S HOSPITAL»}

The Ukrainian healthcare system has been in the reform phase for several years in a row: on April 1, 2020, Phase 2 began, according to which national medical institutions receive funding from the National Healthcare Service. In the new conditions, health care institutions face new challenges: 1) to learn to look for sources of funding on their own; 2) analyze and select 
effective medical technologies; 3) monitor and analyze medical services markets; 4) to establish effective communications with patients, etc.

The solution of new tasks for each medical institution is significantly facilitated by the introduction of strategic processes: clarification of its role in the external environment - the mission; concretization of the seeing of one's future state - the vision; awareness of benefits for their own employees - the goals; preparation of the main document - a strategy that should be legitimized at the general meeting of employees and familiarize key stakeholders with it.

However, a significant number of medical institutions have not yet been able to effectively adapt to the new socio-economic conditions of their operation due to lack of knowledge and experience in applying modern methods and tools of strategic and operational management. Among such methods, the most popular is the method of SWOT-analysis, which is used primarily in the strategic diagnosis of the environment in which the company operates, and is a precondition for further development of strategic documents.

The need for SWOT-analysis as a stage in the process of developing the Development Strategy of the municipal enterprise «Rivne Regional Children's Hospital» (hereinafter - KP "RODL") was caused by the following phenomena and processes: a) lack of approved development strategy of the enterprise; b) global challenges that have arisen for Ukrainian medical institutions; c) risks facing the economy of Ukraine in recent years; d) trends in the development of medicine in the EU; e) signing the Association Agreement with the EU; f) requests of the company's management for the implementation of strategic and operational management.

SWOT-analysis of the utility company «Rivne Regional Children's Hospital» was carried out by a working group of the company with the consent of employees of the Department of Management of the National University of Water and Environmental Engineering, representatives of the NGO «Regional Center for European Integration Projects». It was based on indicators of socio-economic status and prospects of enterprise development, the results of its positioning on various scales, the results of research of global challenges and forecasting of national risks in the medical area, trends in medicine in the reform, as well as identifying problems and growth points, its employees and members of the working group.

As a result of work on the draft development strategy of KP «RODL», one of the important processes of which was SWOT-analysis, we can identify six main stages of strategy, which can be used as recommendations for similar development strategy of other medical institutions: Stage 1 - project preparation on the formation of a working group, which is approved by the chief physician; Stage 2 - holding thematic «round tables», «master classes» to discuss the problems of enterprise development and the formation of focus groups; Stage 3 - conducting sociological surveys of staff, 
members of the working group; Stage 4 - formation of a draft strategy by the working group with the involvement of scientists; Stage 5 - discussion of the draft Strategy at a joint round table with the participation of heads of structural units; Stage 6 - approval of the strategy for the general meeting of employees of the medical institution with the involvement of key stakeholders.

Achieving strategic goals will serve as a guide for approaching the vision and mission of the hospital, as well as a basis for formulating operational goals and further implementation of operational management in KP «RODL».

Keywords: mission; vision; strategy; SWOT-analysis; strategic and operational management; medical reform; communal enterprise «Rivne Regional Children's Hospital» (KP «RODL»).

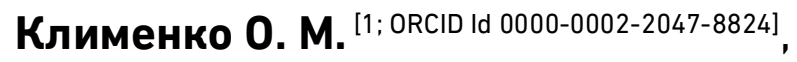
д.с.-Х.н., профессор,

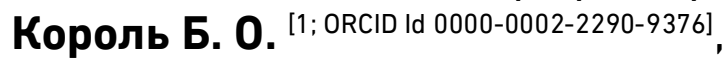
к.э.н., доцент

${ }^{1}$ Национальный университет водного хозяйства и природопользования, г. Ровно

\section{ИСПОЛЬЗОВАНИЕ МЕТОДА SWОТ-АНАЛИЗА КАК ПРЕДУСЛОВИЯ ВНЕДРЕНИЯ СТРАТЕГИЧЕСКОГО И ОПЕРАЦИОННОГО МЕНЕДЖМЕНТА НА КП «РОВЕНСКАЯ ОБЛАСТНАЯ ДЕТСКАЯ БОЛЬНИЦА»}

В статье проанализированы внутренняя и внешняя среды одного из ведущих медицинских учреждений Ровенской области - коммунального предприятия «Ровенская областная детская больница». По результатам использованного метода SWOT-анализа сформулированы видение, миссия. Методом декомпозиции видение и миссия детализированы до уровня стратегических целей дальнейшего развития, что является главным предусловием внедрения стратегического и операционного менеджмента.

Ключевые слова: миссия; видение; стратегия; SWOT-анализ; стратегический и операционный менеджмент; медицинская реформа; коммунальное предприятие «Ровенская областная детская больница» (КП «РОДЛ»). 